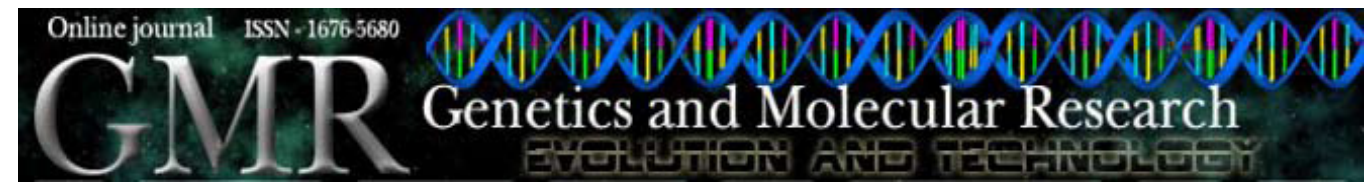

\title{
Genetic population differentiation of the blue swimming crab Portunus pelagicus (Portunidae) in Thai waters revealed by RAPD analysis
}

\author{
S. Klinbunga ${ }^{1,2}$, V. Yuvanatemiya ${ }^{3}$, S. Wongphayak ${ }^{3}$, K. Khetpu ${ }^{4}$, \\ P. Menasveta ${ }^{2,5}$ and B. Khamnamtong ${ }^{1,2}$ \\ ${ }^{1}$ Aquatic Molecular Genetics and Biotechnology Laboratory, \\ National Center for Genetic Engineering and Biotechnology, \\ National Science and Technology Development Agency, Klong 1, \\ Klong Luang, Pathumthani, Thailand \\ ${ }^{2}$ Center of Excellence for Marine Biotechnology, \\ Faculty of Science, Chulalongkorn University, Bangkok, Thailand \\ ${ }^{3}$ Faculty of Marine Technology, Burapha University, \\ Chanthaburi Campus, Chanthaburi, Thailand \\ ${ }^{4}$ Program in Biotechnology, Faculty of Science, \\ Chulalongkorn University, Bangkok, Thailand \\ ${ }^{5}$ Department of Marine Science, Faculty of Science, \\ Chulalongkorn University, Bangkok, Thailand \\ Corresponding author: B. Khamnamtong \\ E-mail: bavornlak@biotec.or.th
}

Genet. Mol. Res. 9 (3): 1615-1624 (2010)

Received May 14, 2010

Accepted June 12, 2010

Published August 17, 2010

DOI 10.4238/vol9-3gmr886

ABSTRACT. Genetic diversity and population differentiation of the blue swimming crab, Portunus pelagicus, in Thailand were analyzed by RAPD analysis. One hundred and twelve RAPD fragments were generated from 109 individuals of P. pelagicus using OPA02, OPA14, OPB10, UBC122, and UBC158 primers. The percentage of polymorphic bands in each geographic sample and that of each primer across overall samples were 72.7-85.0 and 92.0-100\%, respectively. Large numbers of polymorphic bands found in the RAPD analysis suggested high genetic diversity of Thai $P$. pelagicus. The mean genetic distance between 
samples across all primers was 0.0929-0.2471. Significant geographic heterogeneity was observed across samples overall and between all pairs of geographic samples $(\mathrm{P}<0.01$ for $\theta$ and $\mathrm{P}<0.0001$ for the exact test), indicating strong genetic differentiation of $P$. pelagicus in Thai waters, despite its high potential of dispersal. Limited gene flow levels (0.44-1.19 individuals per generation) of Thai P. pelagicus were also observed. A fine scale level of differentiation suggested that $P$. pelagicus from each geographic sample in Thai waters should be regarded as a separate genetic population and treated as a different exploited stock.

Key words: Genetic diversity; Population structure; RAPD; Portunus pelagicus; Species-specific markers

\section{INTRODUCTION}

The blue swimming crab, Portunus pelagicus (Linnaeus) is one of the most important marine species. It is distributed from the intertidal zone to approximately $50 \mathrm{~m}$ depth (Kangas, 2000). In Thailand, P. pelagicus is distributed along the coasts of both the Andaman Sea (west) and the Gulf of Thailand (east) (Naiyanetr, 1998). Commercial fishing of P. pelagicus has been reduced during the last few years. The catch volume of the blue swimming crab in the Gulf of Thailand was reduced from 37,219 metric tons (MT) in 2000 to 22,113 MT in 2004, though the catch in the Andaman Sea remained relatively constant during the same period (6652 to 7411 MT; Ministry of Commerce Thailand, 2005).

The blue swimming crab exhibits moderately long planktonic larval stages (26-45 days) and high mobility during the crab phase (Kangas, 2000). Therefore, high gene flow levels are expected in this species (Edgar, 1990). Currently, P. pelagicus can be cultivated commercially in Thailand.

An initial step to establish appropriate broodstock management and conservation programs and to avoid including inbred founder populations in the breeding programs of this species is the development of molecular genetic markers that can be used for determination of stock structure and evaluation of the levels of gene flow. This information will provide means for more effective management of natural stocks of P. pelagicus (Klinbunga et al., 2007).

Randomly amplified polymorphic DNA (RAPD) analysis has been used to determine genetic diversity and identify useful genetic markers of various marine organisms (TylerWalters and Hawkins, 1995; Tassanakajon et al., 1998; Klinbunga et al., 2000, 2003, 2007). RAPD analysis uses a random oligonucleotide primer, obviating the need for knowledge of the sequences of the genome under investigation (Welsh and McClelland, 1990; Williams et al., 1990). This advantage is particularly useful for a non-model species such as P. pegalicus, for which known nucleotide sequences of both coding and non-coding DNA in this species are rather limited. Moreover, RAPD analysis does not require expensive equipment and extensive steps of analysis (Weising et al., 1995). This makes RAPD analysis suitable for population genetic studies in many species (Klinbunga et al., 2003; Lui and Cordes, 2004; Tang et al., 2005).

Genetic population structure of Australian P. pelagicus was previously reported based on allozyme analysis at seven polymorphic loci ( $A C Y C, A L D H-2, A R G K, P E P-A, P E P-B 2$, $P E P-D 2$, and $P G M$ ) (Bryars and Adams, 1999), six microsatellite loci and polymorphism of a 342-bp fragment of cytochrome oxidase subunit I (COI) (Sezmis, 2004). 
Recently, genetic diversity of P. pelagicus in various regions of Thailand (Ranong, Krabi, Chanthaburi, Prachuap Khiri Khan, and Suratthani) was reported based on AFLP analysis (Klinbunga et al., 2007). Although high genetic diversity and geographic differentiation of $P$. pelagicus were observed, the sample size was rather limited $(\mathrm{N}=72)$. Therefore, estimated genetic diversity and degrees of geographic differentiation may not be accurate.

We examined the genetic diversity and intraspecific population differentiation of $P$. pelagicus in Thai waters, by RAPD analysis, using a larger sample size.

\section{MATERIAL AND METHODS}

\section{Sampling}

One hundred and nine individuals of blue swimming crab (P. pelagicus) were live-

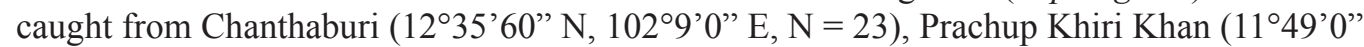
$\left.\mathrm{N}, 99^{\circ} 47^{\prime} 60^{\prime \prime} \mathrm{E}, \mathrm{N}=20\right)$ and Suratthani $\left(9^{\circ} 7^{\prime} 60^{\prime \prime} \mathrm{N}, 99^{\circ} 19^{\prime} 0^{\prime \prime} \mathrm{E}, \mathrm{N}=21\right)$ located in the Gulf of

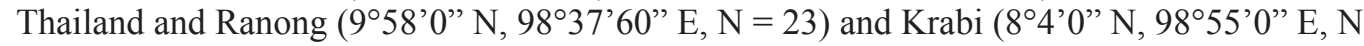
$=22$ ) located in the Andaman Sea (Figure 1). The whole specimens or muscle dissected from the first walking leg of each crab were kept at $-30^{\circ} \mathrm{C}$ until used.

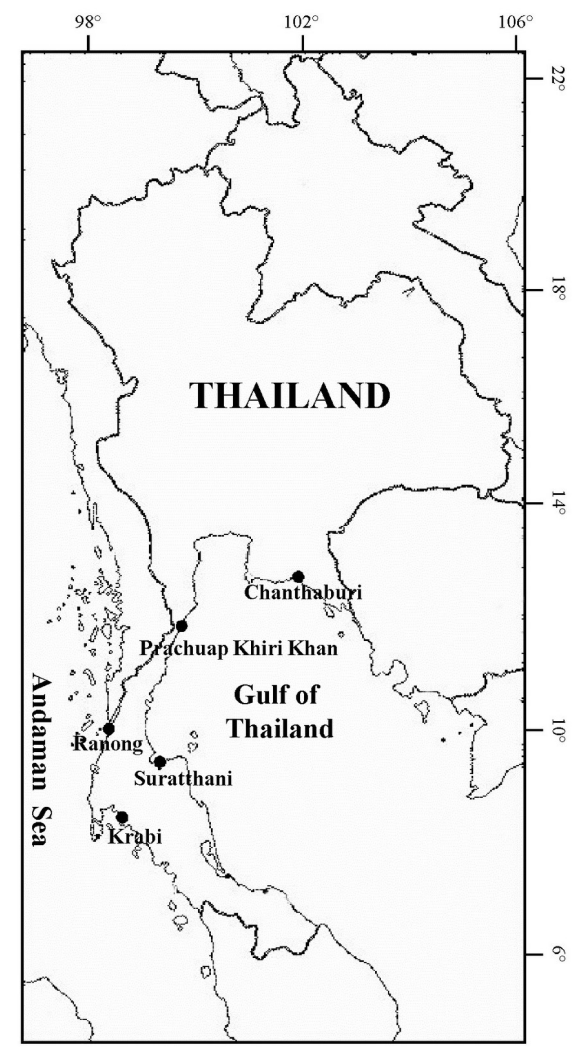

Figure 1. Sampling collection sites of Portunus pelagicus in Thailand. 


\section{DNA extraction}

Genomic DNA was extracted from the muscle of the 1st periopod of each crab using a phenol-chloroform-proteinase $\mathrm{K}$ method (Klinbunga et al., 1996). The concentration of the extracted DNA was spectrophotometrically estimated. DNA was stored at $4^{\circ} \mathrm{C}$ until needed.

\section{RAPD-PCR}

Thirty-one RAPD primers were screened for the amplification success against genomic DNA of a representative individual of P. pelagicus from each geographic sample. Five primers (UBC122, UBC158, OPA02, OPA14, and OPB10) were selected for population genetic analysis of $P$. pelagicus. Polymerase chain reaction (PCR) was performed in a $25-\mu \mathrm{L}$ reaction volume containing $10 \mathrm{mM}$ Tris- $\mathrm{HCl}, \mathrm{pH} 8.8,0.01 \%$ Triton X-100, $50 \mathrm{mM} \mathrm{KCl}, 2 \mathrm{mM} \mathrm{MgCl}$, $100 \mu \mathrm{M}$ of each dNTP, $0.2 \mu \mathrm{M}$ of an arbitrary primer, $1 \mathrm{U}$ DyNazyme ${ }^{\mathrm{TM}}$ II DNA polymerase (Finnzymes, Espoo, Finland) and $25 \mathrm{ng}$ DNA template. The amplification profiles consisted of predenaturation at $94^{\circ} \mathrm{C}$ for $3 \mathrm{~min}$ followed by 40 cycles of denaturation at $94^{\circ} \mathrm{C}$ for $15 \mathrm{~s}$, annealing at $36^{\circ} \mathrm{C}$ for $60 \mathrm{~s}$ and extension at $72^{\circ} \mathrm{C}$ for $90 \mathrm{~s}$. The final extension was carried out at $72^{\circ} \mathrm{C}$ for $7 \mathrm{~min}$. Five microliters of the amplification reaction was electrophoresed through $1.6 \%$ agarose gels and visualized under a UV transilluminator after ethidium bromide staining (Sambrook and Russell, 2001).

\section{Data analysis}

RAPD bands were treated as dominant markers. The percentage of monomorphic $(>95 \%$ of investigated specimens) and polymorphic ( $<95 \%$ of investigated specimens) bands was estimated for each geographic sample. Unbiased genetic distance between pairs of geographic samples was determined (Nei, 1978). Genetic heterogeneity in the allele distribution frequencies of overall samples and between paired geographic samples was examined using the exact test (Raymond and Rousset, 1995). The $F_{\mathrm{ST}}$-based statistics $(\theta)$ between pairs of geographic samples, performing 10,000 iterations to generate the $95 \%$ bootstrapping confidence interval, was estimated. The $\chi^{2}$ value was calculated and tested to determine whether $\theta$ was significantly different from zero (Weir and Cockerham, 1984), using $\chi^{2}=2 \mathrm{~N} \theta(\mathrm{k}-1)$ and d.f. $=(\mathrm{k}-1)(\mathrm{s}-1)$, where $\mathrm{N}=$ number of investigated individuals, $\mathrm{k}=$ number of allele per locus and $\mathrm{s}=$ number of geographic samples. These population genetic parameters were analyzed with Tools for Population Genetic Analysis (TFPGA) (Miller, 1997). The significance level of multiple comparisons was further adjusted using a sequential Bonferroni's method (Rice, 1989). Genetic exchange among population per generation was estimated using $N_{\mathrm{e}} m=1-\theta / 4 \theta$ (Hudson et al., 1992).

\section{RESULTS}

Among 31 RAPD primers that were screened, 26 (UBC119, UBC122, UBC135, UBC138, UBC158, UBC169, UBC174, UBC191, UBC222, UBC228, UBC263, UBC268, UBC273, UBC299, UBC457, UBC458, UBC459, OPA01, OPA02, OPA06, OPA14, OPA15, OPA17, OPB10, OPZ09, and YNZ22) successfully amplified genomic DNA of representative individuals of $P$. pelagicus $(\mathrm{N}=5)$. Five primers (UBC122, UBC158, OPA02, OPA14, and 
OPB10) exhibiting reproducible and easy scoring results were selected for population genetic studies of $P$. pelagicus in Thai waters (Figure 2).

A

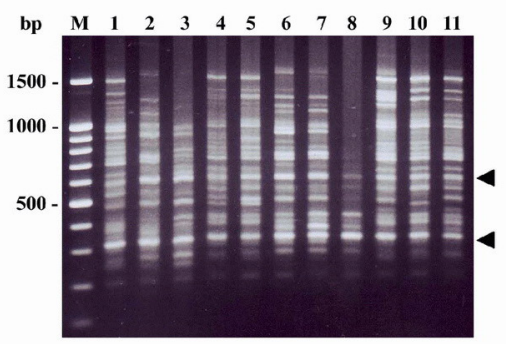

C

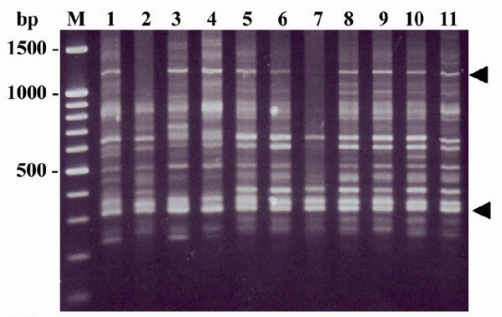

E

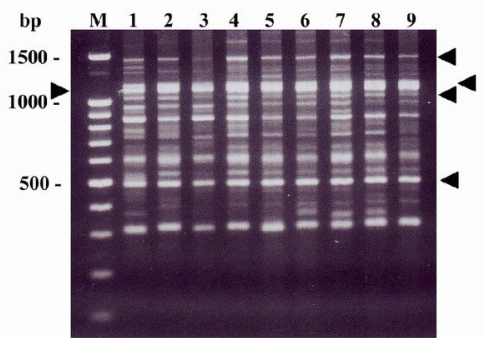

\section{B}

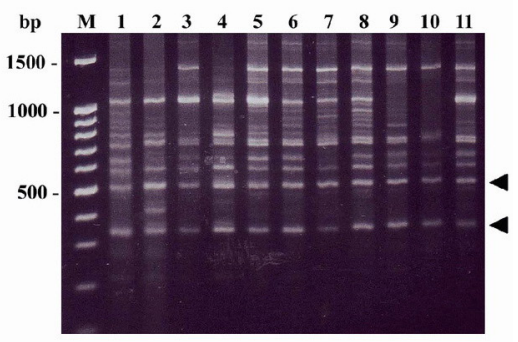

D

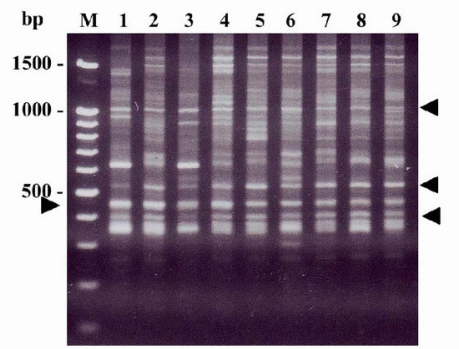

Figure 2. Examples of RAPD patterns of Portunus pelagicus originating from Chanthaburi (lanes 1-2, A-E), Ranong (lanes 3-4, A-E), Suratthani (lanes 5-6, A-E), Krabi (lanes 7-8, A-E), and Prachuap Khiri Khan (lanes 9-11, A-C and lane 9, D-E) generated by OPA02 (A), OPA14 (B), OPB10 (C), UBC122 (D), UBC158 (E). M = 100-bp DNA ladder. Arrowheads indicate candidate species-specific RAPD fragments for P. pelagicus.

One hundred and twelve RAPD fragments ranging from 220 to $1500 \mathrm{bp}$ in length were generated (Table 1). High genetic polymorphism was observed in all geographic samples. The percentage of polymorphic bands for each primer across all geographic samples was 92.0$100 \%$ (Table 1). The Chanthaburi sample exhibited the highest percentage of polymorphic bands, followed by Prachuap Khiri Khan, Ranong, Krabi, and Suratthani (Table 2). Four, 5, 2, 2, and 2 candidate species-specific RAPD markers were generated from UBC122, UBC158, OPA02, OPA14, and OPB10, respectively (Figure 2 and Table 3). Population-specific RAPD fragments were not found in any of these geographic samples. The mean genetic distance between samples for all primers was 0.0929-0.2471 (Table 4). 
Table 1. Sequences of arbitrary primers, sizes and number of amplified bands, and the percentage of polymorphic bands resulting from random amplified polymorphic DNA (RAPD) analysis of Portunus pelagicus using UBC122, UBC158, OPA02, OPA14, and OPB10 primers.

\begin{tabular}{llccr}
\hline Primer & Sequence & Size range (bp) & No. of RAPD bands & Polymorphic bands (\%) \\
\hline UBC122 & 5'-GTAGACGAGC-3' & $320-1200$ & 22 & $21(95.5 \%)$ \\
UBC158 & 5'-TAGCCGTGGC-3' & $310-1500$ & 24 & $23(95.8 \%)$ \\
OPA02 & 5'-TGCCGAGCTG-3' & $250-1500$ & 25 & $23(92.0 \%)$ \\
OPA14 & 5'-TCTGTGCTGG-3' & $340-1400$ & 22 & $22(100 \%)$ \\
OPB10 & 5'-CTGCTGGGAC-3' & $220-1500$ & 19 & $18(94.7 \%)$ \\
Overall primers & - & $220-1500$ & 112 & $107(95.5 \%)$ \\
\hline
\end{tabular}

Table 2. Total number of bands, percentage of polymorphic and monomorphic bands of each geographic sample of Portunus pelagicus in Thai waters revealed by RAPD analysis using UBC122, UBC158, OPA02, OPA14, and OPB10 primers.

\begin{tabular}{|c|c|c|c|c|c|c|}
\hline & UBC122 & UBC158 & OPA02 & OPA14 & OPB10 & Total \\
\hline \multicolumn{7}{|l|}{ Chanthaburi $(\mathrm{N}=23)$} \\
\hline No. of bands & 21 & 23 & 23 & 22 & 18 & 107 \\
\hline No. of polymorphic bands & 18 & 19 & 19 & 19 & 16 & $91(85.0 \%)$ \\
\hline No. of monomorphic bands & 3 & 4 & 4 & 3 & 2 & $16(15.0 \%)$ \\
\hline \multicolumn{7}{|l|}{ Ranong $(\mathrm{N}=23)$} \\
\hline No. of bands & 22 & 24 & 25 & 22 & 17 & 110 \\
\hline No. of polymorphic bands & 17 & 15 & 23 & 21 & 15 & $91(82.7 \%)$ \\
\hline No. of monomorphic bands & 5 & 9 & 2 & 1 & 2 & $19(17.3 \%)$ \\
\hline \multicolumn{7}{|l|}{ Suratthani $(N=21)$} \\
\hline No. of bands & 21 & 24 & 24 & 22 & 19 & 110 \\
\hline No. of polymorphic bands & 17 & 14 & 21 & 13 & 15 & $80(72.7 \%)$ \\
\hline No. of monomorphic bands & 4 & 10 & 3 & 9 & 4 & $30(27.3 \%)$ \\
\hline \multicolumn{7}{|l|}{ Krabi $(\mathrm{N}=22)$} \\
\hline No. of bands & 19 & 22 & 24 & 16 & 19 & 100 \\
\hline No. of polymorphic bands & 14 & 17 & 22 & 12 & 17 & $82(82.0 \%)$ \\
\hline No. of monomorphic bands & 5 & 5 & 2 & 4 & 2 & $18(18.0 \%)$ \\
\hline \multicolumn{7}{|l|}{ Prachuap Khiri Khan $(\mathrm{N}=20)$} \\
\hline No. of bands & 19 & 20 & 23 & 13 & 16 & 91 \\
\hline No. of polymorphic bands & 16 & 18 & 19 & 9 & 14 & $76(83.5 \%)$ \\
\hline No. of monomorphic bands & 3 & 2 & 4 & 4 & 2 & $15(16.5 \%)$ \\
\hline
\end{tabular}

Table 3. Candidate species-specific fragments of Portunus pelagicus in Thailand revealed by random amplified polymorphic DNA (RAPD) analysis.

\begin{tabular}{ll}
\hline Primer & RAPD marker (bp) \\
\hline OPA02 & 300 and 590 \\
OPA14 & 340 and 500 \\
OPB10 & 310 and 1200 \\
UBC122 & $400,440,510$, and 1050 \\
UBC158 & $500,1050,1150,1200$, and 1500 \\
\hline
\end{tabular}

\begin{tabular}{|c|c|c|c|c|c|}
\hline & Chanthaburi (E) & Suratthani (E) & Prachuap Khiri Khan (E) & Ranong (W) & Krabi (W) \\
\hline Chanthaburi (E) & - & 0.9109 & 0.8974 & 0.8351 & 0.8645 \\
\hline Suratthani $(E)$ & 0.0933 & - & 0.8666 & 0.8842 & 0.8363 \\
\hline Prachuap Khiri Khan (E) & 0.1083 & 0.1432 & - & 0.7811 & 0.9113 \\
\hline Ranong (W) & 0.1802 & 0.1230 & 0.2471 & - & 0.8525 \\
\hline $\operatorname{Krabi}(\mathrm{W})$ & 0.1456 & 0.1788 & 0.0929 & 0.1596 & - \\
\hline
\end{tabular}

$\mathrm{E}=$ east; $\mathrm{W}=$ west. 
Geographic heterogeneity analysis of all primers indicated significant differences for overall samples and between all pairs of geographic samples $(\mathrm{P}<0.0001$ for the exact test and $\mathrm{P}<0.01$ for $\theta$; Table 5). The gene flow level $\left(N_{\mathrm{e}} m\right)$ between pairs of geographic samples of $P$. pelagicus was 0.44-1.19 individual per generation.

\begin{tabular}{l} 
Table 5. Geographic heterogeneity analysis of five conspecific samples of Portunus pelagicus based on $F_{\mathrm{ST}}$-based \\
statistics $(\theta)$ and the exact test. \\
\hline Geographic sample \\
\cline { 2 - 3 }
\end{tabular}

\section{DISCUSSION}

Using RAPD-PCR, relatively high genetic diversity was found in P. pelagicus. The percentage polymorphic bands in each of the geographic samples of P. pelagicus ranged from 72.7$85.0 \%$, which is slightly greater than that previously reported for the giant tiger shrimp, Penaeus monodon (51.1-57.7\%; Tassanakajon et al., 1998), Crassostrea oysters (53.2-77.7\%; Klinbunga et al., 2001) and the mud crabs (Scylla serrata, S. oceanica, and S. tranquebarica; Klinbunga et al., 2000) but lower than that of the tropical abalone, Haliotis asinina (81.3-90.5\%; Tang et al., 2005 ) and Saccostrea oysters (86.2-99.4\%; Klinbunga et al., 2001) in Thai waters.

Several unique RAPD fragments exhibiting fixed frequencies were identified. These fragments were considered as potential species-specific markers for $P$. pelagicus. Klinbunga et al. (2010) further developed species-specific markers of $P$. pelagicus and five of 15 candidate species-specific RAPD fragments (OPA14-500, UBC158-500, UBC122-510, UBC158-1200, and UBC158-1500; Table 3) identified in this study were cloned and sequenced. Three RAPDderived sequence-characterized amplified region (SCAR) markers (called PP-SCAR ${ }_{152}$, PP$\mathrm{SCAR}_{397}$ and PP-SCAR 262 derived from UBC122-510, UBC158-1200 and UBC158-1500, respectively) generated the expected product in 95,100 and $100 \%$ of $P$. pelagicus $(\mathrm{N}=174)$ and in all individuals of the three spot swimming crab, P. sanguinolentus $(\mathrm{N}=10)$ but not in the swimming crab, Charybdis crucifera $(\mathrm{N}=20)$ and mud crabs; Scylla oceanica $(\mathrm{N}=18)$, S. serrata $(\mathrm{N}=7)$, $S$. tranquebarica $(\mathrm{N}=9)$. Single-strand conformational polymorphism (SSCP) analysis of PP-SCAR ${ }_{397}$ and $\mathrm{PP}_{-} \mathrm{SCAR}_{262}$ was applied and was sufficient to distinguish $P$. pelagicus from $P$. sanguinolentus unambiguously.

Large genetic distances between pairs of geographic samples were observed; these values indirectly reflected degrees of within species differentiation of Thai $P$. pe- 
lagicus. Generally, paired geographic samples that were situated farther apart geographically did not exhibit greater genetic distance.

Our results from this study were drawn solely from sharing of RAPD-amplified fragments after electrophoresis. The possibility of comigration of RAPD fragments having different sequences but similar sizes cannot be excluded. Homology of comigrating diagnostic fragments should be further verified (Hadrys et al., 1992). This would result in more valid and stable data for subsequent applications in conservation and breeding programs of $P$. pelagicus.

$\mathrm{Lu}$ et al. (2000) analyzed three species of mitten crabs (Eriocheir sinensis, E. japonicus and E. japonicus hepuensis) and three geographic samples of $E$. sinensis by RAPD analysis. No species diagnostic markers were found, but significant genetic differences were found between taxa $(\mathrm{P}<0.001)$ and geographic samples $(\mathrm{P}<0.001)$; intraspecific similarities were larger than interspecific similarity, and intrapopulational similarity was larger than interpopulational similarities.

Intraspecific genetic subdivisions of the Pacific blue shrimp (P. stylirostris) on the east coast of the Gulf of California (Mexico) have also been studied with RAPD analysis. Seventyeight individuals of $P$. stylirostris from six fishing grounds $(\mathrm{N}=13$ per location) were analyzed with eight informative primers (OPM04, 11, 12, 14, 16, 17, 19, and 20). Three hundred and twenty-four RAPD fragments were obtained. Analysis of molecular variance (AMOVA) and pairwise between-population $\Phi_{\mathrm{ST}}$ indicated significant genetic differentiation of $P$. stylirostris $(\mathrm{P}=0.0001$; Aubert and Lighter, 2000).

Previously, intraspecific population differentiation of $P$. pelagicus, originating from the same geographic locations in this study, was reported based on amplified fragment length polymorphism (AFLP) analysis. High genetic diversity of P. pelagicus in Thai waters was found ( $\mathrm{N}=$ 72). A total of 227 AFLP were generated from four primer combinations $\left(\mathrm{P}_{\mathrm{ACC}} / \mathrm{M}_{\mathrm{CAA}}, \mathrm{P}_{\mathrm{AGT}} / \mathrm{M}_{\mathrm{CAA}}\right.$, $\mathrm{P}_{\mathrm{AGT}} / \mathrm{M}_{\mathrm{CAC}}$, and $\mathrm{P}_{\mathrm{ATC}} / \mathrm{M}_{\mathrm{CAA}}$. The percentage of polymorphic bands in each geographic sample was $66.19-94.38 \%$. The mean genetic distance between pairs of samples was 0.1151-0.2440. Geographic heterogeneity analyses using the exact test and $F_{\mathrm{ST}}$-based statistics between all pairwise comparisons were statistically significant $(\mathrm{P}<0.01)$, indicating a fine-scale level of intraspecific population differentiation of Thai $P$. pelagicus. The estimated number of migrants per generation $\left(N_{\mathrm{e}} m\right)$ was $0.26-0.76$, suggesting restricted gene flow levels of P. pelagicus (Klinbunga et al., 2007).

Likewise, geographic heterogeneity analysis based on each RAPD primer indicated significant genetic heterogeneity among 43 of 50 possible comparisons, after a sequential Bonferroni's adjustment $(\mathrm{P}<0.01$; data not shown). The combined data confirmed a fine scale level of population subdivisions among all pairwise comparisons of $P$. pelagicus previously reported by AFLP analysis $(\mathrm{P}<0.0001$ for the exact test and $\mathrm{P}<0.01$ for $\theta$ ). The lower bootstrapping $95 \%$ confidence interval of overall samples and paired geographic samples overall loci was also much greater than zero $(0.2227$ and $0.1226-0.3023)$. This result further supports the affirmation of genetic differentiation between conspecific samples of P. pelagicus $(\mathrm{P}<0.0001)$.

Surprisingly, patterns of genetic differentiation (e.g., between pairs of geographic samples) based on RAPD analysis did not indicate long range migration of $P$. pelagicus in our study, and the patterns were different from those of other marine species locally found in Thai waters, including $P$. monodon (Khamnamtong et al., 2009), P. merguiensis (Hualkasin et al., 2003), H. asinina (Praipue et al., 2010) and H. varia (Klinbunga et al., 2003); in these previous studies, significant genetic heterogeneity was found between coastal regions (i.e., between the Andaman Sea and the Gulf of Thailand).

Generally, P. pelagicus is regarded as a potential vagile species; females migrate out of estuaries into the open ocean for spawning, and both females and males migrate out as a re- 
action to lowered salinity (Meagher, 1971; Potter et al., 1983). However, the high level of population differentiation that we observed indicates that $P$. pelagicus experienced restricted gene flow levels $\left(N_{\mathrm{e}} m<1\right.$ for almost all comparisons). Geographic distances between the samples (Bryars and Adams, 1999; Sezmis, 2004), non-concurrent male and female maturation periods (Pillay and Nair, 1971; Kailola et al., 1993; Kangas, 2000) and migratory behavior of $P$. pelagicus may have been responsible for the present differentiation of its gene pool. Migration distance and population dynamics of $P$. pelagicus in Thai waters are relatively unknown and should be further studied to help explain the unexpectedly low gene flow levels in this species.

Although analysis of genetic diversity and population genetics of organisms by AFLP is normally more reliable than with RAPD analysis, in our study the two approaches were sufficient to examine genetic differentiation of P. pelagicus in Thailand. The RAPD technique is simpler and more cost-effective than AFLP analysis for monitoring genetic diversity levels of $P$. pelagicus.

Molecular population genetic studies provide necessary information required for increasing the efficiency of management of P. pelagicus. The blue swimming crab in Thailand is presently perceived and managed as a single stock. Basic knowledge about high genetic diversity and large genetic divergence between geographic samples at a fine scale level lead us to suggest that P. pelagicus from each geographic sample in Thai waters should be regarded as a separate genetic population and treated as a different exploited stock (Carvalho and Hauser, 1994; Conover et al., 2006). A genetic-based stock enhancement program should be implemented to resolve problems of overexploitation, as illustrated by an increasing proportion of small sizes of captured P. pelagicus (Klinbunga et al., 2007) and to maintain the genetic diversity of Thai P. pelagicus.

\section{ACKNOWLEDGMENTS}

Research supported by the National Center for Genetic Engineering and Biotechnology (BIOTEC), National Science and Technology Development Agency (NSTDA), Thailand, with a grant awarded to S. Klinbunga.

\section{REFERENCES}

Aubert H and Lighter DV (2000). Identification of genetic populations of the Pacific blue shrimp Penaeus stylirostris of the Gulf of California, Mexico. Mar. Biol. 137: 875-885.

Bryars SR and Adams M (1999). An allozyme study of the blue swimming crab, Portunus pelagicus (Crustacean: Portunidae), in Australia: stock delineation in southern Australia and evidence for a cryptic species in northern waters. Mar. Freshwater Res. 50: 15-26.

Carvalho GR and Hauser L (1994). Molecular genetics and the stock concept in fisheries. Rev. Fish Biol. Fish. 4: 326-350.

Conover DO, Clarke LM, Munch SB and Wagner GN (2006). Spatial and temporal scales of adaptive divergence in marine fishes and its implications for conservation. J. Fish B. 69 (Suppl C): 21-47.

Edgar GJ (1990). Predator-prey interactions in seagrass beds. II. Distribution and diet of the blue manna crab Portunus pelagicus Linnaeus at Cliff Head, Western Australia. J. Exp. Mar. Biol. Ecol. 139: 23-32.

Hadrys H, Balick M and Schierwater B (1992). Applications of random amplified polymorphic DNA (RAPD) in molecular ecology. Mol. Ecol. 1: 55-63.

Hualkasin W, Sirimontaporn P, Chotigeat W, Querci J, et al. (2003). Molecular phylogenetic analysis of white prawn species and the existence of two clades in Penaeus merguiensis. J. Exp. Mar. Biol. Ecol. 296: 1-11.

Hudson RR, Slatkin M and Maddison WP (1992). Estimation of levels of gene flow from DNA sequence data. Genetics 132: 583-589.

Kailola PJ, Williams MJ, Stewart PC and Reichelt RE (1993). Australian Fisheries Resources. Bureau of Resource Sciences, Department of Primary Industries and Energy, and the Fisheries Research and Development Corporation, Canberra, Australia, 422. 
Kangas MI (2000). Synopsis of the biology and exploitation of the blue swimmer crab, Portunus pelagicus Linnaeus, in Western Australia. Fish Res. Rep. Fish West Aus. 121: 1-22.

Khamnamtong B, Klinbunga S and Menasveta P (2009). Genetic diversity and geographic differentiation of the giant tiger shrimp (Penaeus monodon) in Thailand analyzed by mitochondrial COI sequences. Biochem. Genet. 47: 42-55.

Klinbunga S, Sodsuk S, Penman DJ and McAndrew BJ (1996). An improved protocol for total DNA isolation and visualisation of mtDNA-RFLP(s) in tiger prawn, Penaeus monodon. Thai J. Aquat. Sci. 3: 36-41.

Klinbunga S, Boonyapakdee A and Pratoomchat B (2000). Genetic diversity and species-diagnostic markers of mud crabs (genus Scylla) in eastern Thailand determined by RAPD analysis. Mar. Biotechnol. 2: 180-187.

Klinbunga S, Ampayup P, Tassanakajon A, Jarayabhand P, et al. (2001). Genetic diversity and molecular markers of cupped oysters (genera Crassostrea, Caccostrea, and Striostrea) in Thailand revealed by randomly amplified polymorphic DNA analysis. Mar. Biotechnol. 3: 133-144.

Klinbunga S, Pripue P, Khamnamtong N, Puanglarp N, et al. (2003). Genetic diversity and molecular markers of the tropical abalone (Haliotis asinina) in Thailand. Mar. Biotechnol. 5: 505-517.

Klinbunga S, Khetpu K, Khamnamtong B and Menasveta P (2007). Genetic heterogeneity of the blue swimming crab (Portunus pelagicus) in Thailand determined by AFLP analysis. Biochem. Genet. 45: 725-736.

Klinbunga S, Thamniemdee N, Yuvanatemiya V, Khetpu K, et al. (2010). Species identification of the blue swimming crab Portunus pelagicus in Thai waters using mtDNA and RAPD-derived SCAR markers. Aquaculture (in press).

Lu R, Qiu T, Xiang C and Xie H (2000). RAPD and AFLP techniques for the analysis of genetic relationships in two genera of Decapoda. Crustaceana 73: 1027-1036.

Lui ZJ and Cordes JF (2004). DNA markers, technologies and their applications in aquaculture genetics. Aquaculture 238: 1-37.

Meagher TD (1971). Ecology of the Crab Portunus pelagicus (Crustacean: Portunidae) in South Western Australia. Ph.D. thesis, University of Western Australia, Perth.

Miller MP (1997). Tools for Population Genetic Analyses (TFPGA) 1.3: A Window Program for the Analysis of Allozyme and Molecular Population Genetic Data. Department of Biological Sciences, Northern Arizona University, Flagstaff.

Ministry of Commerce Thailand (2005). Total Production Volume and Value. 2001-2005. Ministry of Commerce Thailand, Bangkok.

Naiyanetr P (1998). Checklist of the Crustacean Fauna in Thailand (Decapoda and Stomatopoda). Office of Environmental Policy and Planning Biodiversity, Series 5, 161, Bangkok.

Nei M (1978). Estimation of average heterozygosity and genetic distance from a small number of individuals. Genetics 89: 583-590.

Pillay KK and Nair NB (1971). The annual reproductive cycles of Uca annulipes, Portunus pelagicus and Metapenaeus affinis (Decapoda: Crustacea) from the south-west coast of India. Mar. Biol. 11: 152-166.

Potter IC, Chrystal PJ and Loneragan NR (1983). The biology of the blue manna crab Portunus pelagicus in an Australian estuary. Mar. Biol. 78: 75-85.

Praipue P, Klinbunga S and Jarayabhand P (2010). Genetic diversity of wild and domesticated stocks of Thai abalone, Haliotis asinina (Haliotidae), analyzed by single-strand conformational polymorphism of AFLP-derived markers. Genet. Mol. Res. 9: 1136-1152.

Raymond M and Rousset F (1995). An exact test for population differentiation. Evolution 49: 1280-1283.

Rice WR (1989). Analyzing tables of statistical tests. Evolution 43: 223-225.

Sambrook J and Russell DW (2001). Molecular Cloning: A Laboratory Manual. 3rd edn. Cold Spring Harbor Laboratory Press, New York.

Sezmis E (2004). The Population Genetic Structure of Portunus pelagicus in Australian Waters. Ph.D. thesis, Murdoch University, Perth.

Tang S, Popongviwat A, Klinbunga S, Tassanakajon A, et al. (2005). Genetic heterogeneity of the tropical abalone (Haliotis asinina) revealed by RAPD and microsatellite analyses. J. Biochem. Mol. Biol. 38: 182-190.

Tassanakajon A, Pongsomboon S, Jarayabhand P, Klinbunga S, et al. (1998). Genetic structure in wild populations of black tiger shrimp (Penaeus monodon) using randomly amplified polymorphic DNA analysis. J. Mar. Biotechnol. 6: 249-254.

Tyler-Walters H and Hawkins AR (1995). The application of RAPD markers to the study of the bivalve mollusc Lasaea rubra. J. Mar. Biol. Assoc. 75: 563-569.

Weir BS and Cockerham CC (1984). Estimating F-statistics for the analysis of population structure. Evolution 38: 1358-1370.

Weising K, Nybom H, Wolf K and Meyer W (1995). DNA Fingerprinting in Plant and Fungi. CRC Press, Boca Raton, Florida.

Welsh J and McClelland M (1990). Fingerprinting genomes using PCR with arbitrary primers. Nucleic Acids Res. 18: 7213-7218.

Williams JG, Kubelik AR, Livak KJ, Rafalski JA, et al. (1990). DNA polymorphisms amplified by arbitrary primers are useful as genetic markers. Nucleic Acids Res. 18: 6531-6535. 